Artikel Riset

DOI : 10.33751/jf.v10i1.2069
Fitofarmaka Jurnal Ilmiah Farmasi

Vol.10, No.1, Juni $2020: 76-83$

p-ISSN : 2087-9164 e-ISSN : 2622-755X

\title{
PENGARUH BERBAGAI METODE EKSTRAKSI PADA PENENTUAN KADAR FLAVONOID EKSTRAK ETANOL DAUN ILER (Plectranthus scutellarioides)
}

\author{
Novi Fajar Utami ${ }^{1}$, Sely Meidi Nurdayanty ${ }^{1}$, Sutanto ${ }^{2}$, Usep Suhendar ${ }^{1 *}$ \\ ${ }^{1}$ Program Studi Farmasi, FMIPA Universitas Pakuan, PO Box 452 Bogor 16143 \\ ${ }^{2}$ Program Studi Kimia, FMIPA Universitas Pakuan, Bogor \\ *E-mail: usep.suhendar@unpak.ac.id
}

\begin{abstract}
ABSTRAK
Tanaman iler merupakan tanaman yang berfungsi sebagai tanaman obat tradisional. Senyawa flavonoid pada tanaman iler memiliki aktivitas sebagai antioksidan. Kadar flavonoid pada ekstrak salah satunya dipengaruhi oleh metode ekstraksi yang digunakan. Penelitian ini bertujuan untuk menentukan metode ekstraksi yang terbaik untuk menghasilkan kadar flavonoid tertinggi dalam ekstrak etanol $70 \%$ daun iler. Metode ekstraksi yang digunakan meliputi Maserasi, Refluks, Microwave Assisted Extraction (MAE), dan Ultrasound-Assisted Extraction (UAE). Penetapan kadar flavonoid ekstrak etanol $70 \%$ daun iler dilakukan secara spektrofotometri UV-Vis menggunakan pereaksi $\mathrm{AlCl}_{3}$. Hasil penelitian menunjukkan bahwa metode ekstraksi yang terbaik untuk menghasilkan kadar flavonoid tertinggi dalam ekstrak etanol $70 \%$ daun iler yaitu metode Microwave Assisted Extraction. Kadar flavonoid dengan metode maserasi, refluks, Microwave Assisted Extraction dan Ultrasound Assisted Extraction berturut-turut sebesar 0,41\%, 0,45\%, 0,75\%, dan 0,62\%.
\end{abstract}

Kata kunci: Plectranthus scutellarioides, flavonoid, maserasi, refluks, MAE, UAE

\section{THE EFFECT OF VARIOUS METHODS OF EXTRACTION ON FLAVONOID LEVELS FLOWER LEAF EXTRACT (Plenctranthus scutellariodes)}

\begin{abstract}
The Iler plants was plants that function as traditional medicinal plants. Flavonoid compounds in iler plants have antioxidant activity. One of the flavonoid levels in extracts are influenced by the extraction method used. This study aims to determine the best extraction method to produce the highest levels of flavonoids in $70 \%$ ether extract of iler leaves. Extraction was carried out using the methods of maceration, reflux, Microwave Assisted Extraction (MAE) and Ultrasound Assisted Extraction (UAE). Determination of flavonoid levels in $70 \%$ ethanol extract of iler leaves was p erformed by $\mathrm{UV}$-Vis spectrophotometry using $\mathrm{AlCl}_{3}$ reagent. The results showed that the best extraction method to produce the highest levels of flavonoids in $70 \%$ ether leaf ethanol extract was the Microwave Assisted Extraction method. Flavonoid levels with maceration, reflux, Microwave Assisted Extraction and Ultrasound Assisted Extraction methods, respectively were $0.41 \%, 0.45 \%, 0.75 \%$, and $0.62 \%$.
\end{abstract}

Keywords: Plectranthus scutellarioides, flavonoid, maserasi, refluks, MAE, UAE 


\section{PENDAHULUAN}

Tanaman iler berasal dari Asia Tenggara, tumbuh liar pada tempattempat yang lembab dan terbuka. Corak, bentuk dan warna daun iler bermacammacam, tetapi yang berkhasiat untuk obat adalah daun yang berwarna merah kecoklatan (Dalimartha, 2000)

Senyawa kimia yang terkandung dalam tumbuhan iler adalah senyawa golongan flavonoid, alkaloid, saponin, minyak atsiri, tanin, lemak, fitosterol, kalsium oksalat dan polisakarida (Swantara, 2010). Tumbuhan ini mempunyai khasiat untuk meredakan rasa nyeri, sebagai antiinflamasi, antioksidan, antimikroba, antibakteri dan dapat mempercepat penyembuhan luka (Rahmawati, 2018). Terdapat berbagai macam metode ekstraksi yaitu, metode ekstraksi konvensional dan metode ekstraksi modern.

Metode ekstraksi konvensional diantaranya yaitu maserasi dan refluks. Sedangkan metode esktraksi modern diantaranya yaitu ekstraksi Microwave Assisted Extraction (MAE) dan Ultrasound Assisted Extraction (UAE). Hasil penelitian menunjukkan, ekstraksi mengguna-kan metode MAE pada kulit bawang dengan daya 800 watt selama 6 menit menghasilkan kadar flavonoid sebesar $17,18 \%$ dan ekstraksi menggunakan metode maserasi selama 3 hari pada suhu kamar menghasilkan kadar flavonoid sebesar 14,92\% (Jupersio, 2017). Hasil penelitian lain yang dilakukan pada daun teh putih, menunjukkan bahwa waktu dan suhu optimum yang didapatkan untuk metode UAE yaitu $40^{\circ} \mathrm{C}$ selama 19,5152 menit dengan kadar flavonoid sebesar 0,39\% (Jupersio, 2017). Selain itu, penelitian pada tongkol jagung menunjukkan, ekstraksi menggunakan metode refluks dengan suhu $50^{\circ} \mathrm{C}$ selama 2 jam menghasilkan kadar fenolik sebesar 0,03\% (Fairus, 2016). Maka dari itu, perbedaan metode ekstraksi akan menghasilkan adanya perbedaan kadar suatu senyawa.

Berdasarkan uraian diatas, penelitian ini bertujuan untuk mengetahui pengaruh berbagai metode ekstraksi terhadap penentuan kadar flavonoid pada ekstrak daun iler.

\section{METODE PENELITIAN \\ Alat dan Bahan}

Alat-alat yang digunakan dalam penelitian adalah: Microwave oven (Samsung $\left.{ }^{\circledR}\right)$, Sonikasi (Sonica®), alat Refluks (Jaluba Perkasa ${ }^{\circledR}$ ), botol kaca maserasi, rotary evaporator (IKA®), Spektrofotometri UV-Vis (Jasco V$730 \AA)$, dan peralatan gelas laboratorium lainnya (Pyrex $\left.{ }^{\circledR}\right)$.

Bahan-bahan yang digunakan dalam penelitian adalah: daun iler segar, etanol 70\% (Brataco), etanol 96\% (Brataco), asam klorida ( $\mathrm{HCl})$ (Marck), kuersetin (Merck), akuades, natrium asetat (Brataco), magnesium (Mg) (Merck), alumunium klorida $\left(\mathrm{AlCl}_{3}\right) 10 \%$ (Merck).

\section{Pembuatan Serbuk Simplisia}

Daun iler yang telah dikumpulkan sebanyak 7,1 kg, di sortasi basah kemudian dicuci dengan air mengalir sampai bersih. Daun iler yang telah bersih kemudian dikeringkan dengan cara di jemur dibawah sinar matahari dari jam 09.00-11.00 pagi dan bagian atas daun dilapisi dengan kain hitam, sehingga tidak terkena paparan cahaya matahari langsung. Setelah kering, dibersihkan kembali dari kotoran-kotoran yang masih me-nempel. Simplisia kering tersebut selanjutnya di grinder hingga menjadi simplisia serbuk, kemudian dihitung rendemennya. 


\section{Karakteristik Serbuk Simplisia Penetapan Kadar Air}

Penetapan kadar air simplisia dilakukan dengan cara gravimetri. Ditimbang simplisia serbuk dan ekstrak kental daun iler dengan teliti masingmasing sebanyak 2 g. Dimasukkan cawan uap yang telah ditara 10 menit dalam oven $105^{\circ} \mathrm{C}$, diuapkan di dalam oven $105^{\circ} \mathrm{C}$ hingga berat konstan.

\section{Penetapan Kadar Abu}

Ditimbang dengan teliti kurang lebih $2 \mathrm{~g}$ serbuk simplisia daun iler ke dalam krus silikat yang telah dipijarkan dan ditara lalu diratakan. Dipijarkan perlahan-lahan dalam tanur dengan suhu $600^{\circ} \mathrm{C}$ hingga arang habis, didinginkan, ditimbang (Departemen Kesehatan RI, 2000).

\section{Identifikasi Senyawa Flavonoid Serbuk dan Ekstrak Daun Iler}

Identifikasi senyawa flavonoid pada serbuk dan ekstrak daun iler dengan menggunakan pereaksi serbuk $\mathrm{Mg}$.

\section{Pembuatan Ekstrak (Departemen Kesehtan RI, 2013)}

Serbuk simplisia daun iler yang digunakan untuk setiap ekstraksi adalah sebanyak $50 \mathrm{~g}$ dengan menggunakan pelarut etanol $70 \%$.

\section{Maserasi}

Pada proses maserasi seluruh serbuk simplisia dimasukkan ke dalam wadah tertutup dan direndam dalam 300 ml pelarut pertama, dibiarkan selama 6 jam sambil sesekali dikocok, kemudian didiamkan selama 18 jam pada suhu kamar. Filtrat dan residu dipisahkan kemudian residu yang dihasilkan dimaserasi kembali dengan $150 \mathrm{~mL}$ pelarut menggunakan proses yang sama. Proses ini dilakukan terus-menerus sampai warna filtrat yang dihasilkan konstan. Filtrat dikumpulkan dan diuapkan menggunakan rotary evaporator sampai menjadi ekstrak kental.

\section{Refluks}

Serbuk simplisia dimasukkan ke dalam alat refluks kemudian dimasukkan pelarut sebanyak $300 \mathrm{~mL}$. Setelah terendam, campuran (sampel dan pelarut) direfluks pada suhu $50^{\circ} \mathrm{C}$ selama 2 jam. Residu hasil refluks pertama diekstraksi kembali menggunakan pelarut sebanyak $150 \mathrm{~mL}$ dengan perlakuan yang sama. Dilakukan ekstraksi terus-menerus dengan residu yang sama dan penambahan pelarut 150 $\mathrm{mL}$ sampai warna filtrat yang dihasilkan konstan.

\section{Ultrasound Assisted Extraction (UAE)}

Serbuk simplisia ditempatkan ke dalam Erlenmeyer $500 \mathrm{~mL}$ dan ditambahkan pelarut sebanyak $300 \mathrm{~mL}$. Ditutup dengan alumunium foil, lalu dimasukkan ke dalam sonikator, diekstraksi selama 20 menit pada suhu $40^{\circ} \mathrm{C}$ dan frekuensi gelombang pada 40 $\mathrm{kHz}$. Selanjutnya didiamkan selama 30 menit dan disaring dengan kain batis. Residu hasil sonikasi pertama, diekstraksi kembali dengan pelarut sebanyak $150 \mathrm{~mL}$ dengan perlakuan yang sama. Dilakukan resonikasi terus-menerus sampai warna filtrat menjadi konstan dengan penambahan pelarut $150 \mathrm{~mL}$ (Farida, 2016).

\section{Microwave Assisted Extraction (MAE)}

Serbuk simplisia dimasukkan kedalam erlenmeyer dengan pelarut sebanyak $300 \mathrm{~mL}$, kemudian di oven dengan daya 800 watt selama 6 menit. Larutan diradiasi dalam microwave oven secara berkala (radiasi 1 menit dan 2 menit dimatikan) untuk menjaga suhu 
tidak melebihi $80^{\circ} \mathrm{C}$. Filtrat disaring dan residu diekstraksi kembali menggunakan pelarut sebanyak $150 \mathrm{~mL}$ dengan perlakuan yang sama. Diekstraksi kembali sampai warna filtrat konstan dengan penambahan pelarut $150 \mathrm{~mL}$ (Quan et al, 2006).

\section{Penetapan Kadar Flavonoid}

Sebanyak 0,05 g ekstrak kental dilarutkan ke dalam $50 \mathrm{~mL}$ etanol $70 \%$, kemudian dipipet $10 \mathrm{~mL}$ dari masingmasing ekstrak ke dalam labu ukur $50 \mathrm{~mL}$ dan ditambahkan etanol, natrium asetat dan $\mathrm{AlCl}_{3}$. Serapan diukur dengan spektrofotometri UV-Vis pada panjang gelombang maksimum. Absorban yang dihasilkan dimasukkan ke dalam persamaan regresi liniear dari kurva standar kuersetin.

\section{Analisis Statistik}

Perhitungan statistik dilakukan dengan menggunakan SPSS 26 untuk perangkat Windows. Untuk perbandingan nilai rata-rata, oneway analisis varians (ANOVA) diaplikasikan dan perbedaan dianggap signifikan pada $\mathrm{P}<$ 0,005 .

\section{HASIL DAN PEMBAHASAN \\ Hasil Pembuatan Serbuk} Karakteristik Serbuk Simplisia

dan

Hasil identifikasi tanaman yang dilakukan di Herbarium Bogoriense Bidang Botani Pusat Lembaga - LIPI Cibinong-Bogor, menyatakan bahwa daun iler yang digunakan dalam proses penelitian ini yaitu daun iler dengan nama ilmiah Plectranthus scutellarioides [L.] R. Br. Yang termasuk kedalam family Lamiaceae.

Simplisia serbuk yang diperoleh sebanyak $725 \mathrm{~g}$ dengan rendemen sebesar 10,21\%. Karakteristik simplisia yang dihasilkan yaitu serbuk warna hijau tua,aroma khas dan rasa pahit. Hasil penentuan kadar air yang diperoleh menggunakan metode gravimetri adalah sebesar $8,56 \%$. Hasil ini sudah memenuhi persyaratan dimana syarat kadar air serbuk simplisia pada umumnya yaitu tidak lebih dari 10\% (Departemen Kesehatan RI, 2013).

Hasil penentuan kadar abu yang diperoleh dari serbuk simplisia daun iler adalah $6,23 \%$. Hasil yang diperoleh sudah memenuhi persyaratan dimana syarat kadar abu daun iler tidak lebih dari $8 \%$.

\section{Hasil Identifikasi Flavonoid}

Hasil uji fitokimia yang telah dilakukan, serbuk simplisia dan ekstrak kental etanol daun iler mengandung senyawa flavonoid ditandai dengan dengan terbentuknya warna merah, hal ini terjadi karena reduksi flavonoid dengan $\mathrm{Mg}$ menghasilkan senyawa kompleks yang berwarna merah atau jingga. Hasil uji fitokimia sesuai dengan penelitian sebelumnya yang menyatakan bahwa serbuk simplisia dan ekstrak daun iler mengandung senyawa flavonoid (Riky dan Bambang, 2014). Hasil penelitian lain yang menyatakan, ekstrak kental etanol daun iler positif mengandung senyawa flavonoid (Yustina, 2015).

\section{Hasil Ekstrak Kental Daun Iler}

Dari hasil pengamatan organoleptik ekstrak etanol daun iler dari berbagai metode ekstraksi berupa ekstrak kental berwarna hitam kehijauan dan memiliki bau yang khas. Perhitungan rendemen ekstrak dilakukan untuk menentukan perbandingan jumlah ekstrak yang diperoleh dari suatu bahan terhadap awal berat bahan simplisia serta untuk mengetahui banyaknya senyawa bioaktif yang terkandung dalam bahan yang terekstraksi. Data rendemen ekstrak 
kental etanol daun iler dapat dilihat pada Tabel 1.

Tabel 1. Data Rendemen Ekstrak Kental Etanol 70\% Daun Iler

\begin{tabular}{lc}
\hline Metode Ekstraksi & Rata-rata rendemen $(\%) \pm \mathrm{sd}$ \\
\hline Maserasi & $27,1902 \pm 1,0006$ \\
Refluks & $23,9811 \pm 0,6933$ \\
MAE & $23,9811 \pm 1,6603$ \\
UAE & $22,8449 \pm 1,1116$ \\
\hline
\end{tabular}

Berdasarkan Tabel 1 dapat dilihat bahwa Maserasi dan Refluks memiliki rendemen dan kadar air tertinggi dibandingkan MAE dan UAE. Metode ekstraksi konvensional seperti maserasi dan refluks menghasilkan rendemen lebih tinggi dibandingkan dengan metode ekstraksi modern yaitu MAE dan UAE. Waktu ekstraksi sangat berpengaruh terhadap ekstrak yang dihasilkan. Lamanya waktu ekstraksi akan menghasilkan nilai rendemen yang tinggi dan juga akan meningkatkan penetrasi pelarut kedalam bahan baku (Yulianti et al., 2014).

\section{Hasil Kadar Air Ekstrak Kental}

Penentuan kadar air ekstrak kental etanol daun iler dilakukan dengan metode gravimetri. Hasil kadar air ekstrak kental dari masing-masing proses ekstraksi dapat dilihat pada Tabel 2.

Tabel 2. Data Kadar Air Ekstrak Kental Etanol 70\% Daun Iler

\begin{tabular}{lc}
\hline Metode Ekstraksi & Rata-rata rendemen $(\%) \pm$ sd \\
\hline Maserasi & $27,5107 \pm 0,9239$ \\
Refluks & $26,3114 \pm 0,8072$ \\
MAE & $25,2110 \pm 0,9875$ \\
UAE & $24,2616 \pm 1,4524$ \\
\hline
\end{tabular}

Kadar air yang diperoleh dari masing-masing metode ekstraksi sangat besar dikarenakan proses ekstraksi menggunakan pelarut etanol $70 \%$. Konsentrasi pelarut etanol $70 \%$ lebih banyak mengandung air dibandingkan dengan konsentrasi etanol $90 \%$, serta semakin lama waktu ekstraksi kadar air yang terdapat dalam bahan akan menguap (Swantara, 2010). Kadar air ekstrak kental etanol $70 \%$ daun iler yang dihasilkan dari berbagai metode ekstraksi sudah memenuhi syarat. Syarat kadar air ekstrak kental yaitu 15-30\%.

\section{Analisis Kadar Flavonoid Ekstrak Kental Etanol Daun Iler}

Penentuan kadar flavonoid dilakukan terhadap ekstrak kental etanol daun iler menggunakan spektrofotometri UV-Vis pada panjang gelombang $433 \mathrm{~nm}$ dengan waktu inkubasi optimum selama 25 menit. Persamaan yang digunakan dalam menentukan kandungan flavonoid adalah persamaan regresi linear yaitu $\mathrm{y}=$ $0,0797 \mathrm{x}-0,0168$ dengan nilai $\mathrm{R}^{2}=$ 0,9996. Nilai linearitas menunjukkan korelasi antara konsentrasi dan absorbansi yang dihasilkan. Semakin baik nilai linearitas (nilai $\mathrm{R}$ sama dengan 1 atau mendekati 1) maka korelasi juga semakin baik.

Kadar flavonoid ekstrak etanol $70 \%$ daun iler tertinggi dihasilkan oleh metode ekstraksi MAE, lalu diikuti oleh metode 
UAE, kemudian refluks dan maserasi. Hasil rata-rata kadar flavonoid ekstrak etanol $70 \%$ daun iler dapat dilihat pada Gambar

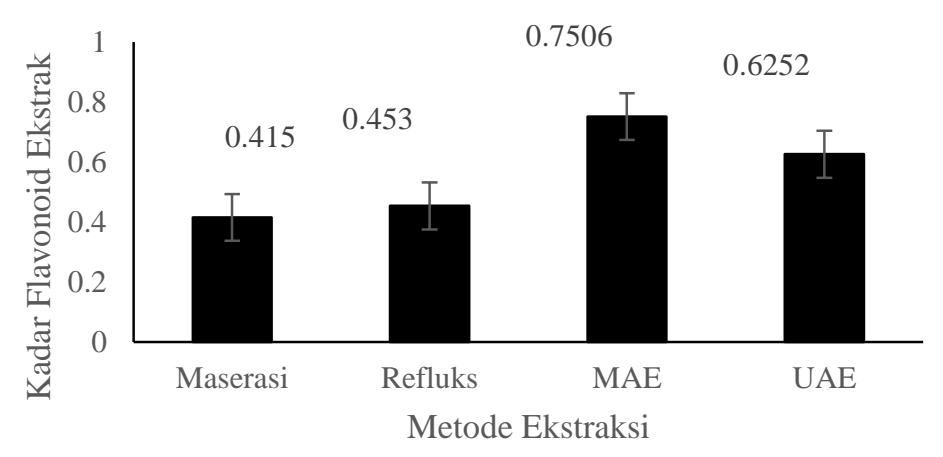

Gambar 1. Kadar senyawa flavonoid ekstrak daun iler dengan berbagai metode ekstraksi.

Metode UAE, mekanisme ekstraksi yang melibatkan getaran gelombang ultrasonik dengan frekuensi diatas $20 \mathrm{kHz}$ $(20000 \mathrm{~Hz})$ dan dibantu dengan sedikit pemanasan yaitu $40^{\circ} \mathrm{C}$. Gelombang ultrasonik dapat memecahkan dinding sel yang akan membantu terlepasnya senyawa aktif keluar. Getaran frekuensi pada UAE yaitu $20000 \mathrm{~Hz}$ dalam 1 detik. Metode MAE, mekanisme ekstraksi yang melibatkan gelombang elektromagnetik pada $2500 \mathrm{MHz}(2,5 \mathrm{GHz})$. Semakin tinggi gelombang elektromagnetik pada MAE maka suhu yang dihasilkan semakin panas. Oleh sebab itu, selama proses ekstraksi harus dikeluarkan setiap 2 menit sekali untuk mencegah terjadinya peluapan.

Energi yang dihasilkan pada MAE yaitu energi radiasi dan energi rotasi. Maka dari itu, adanya radiasi gelombang mikro dan getaran yang berotasi akan mengakibatkan tekanan pada dinding sel meningkat, kemudian sel membengkak (swelling) dan senyawa aktif yang keluar semakin banyak.

Metode ekstraksi refluks, proses ekstraksi menggunakan pemanasan pada $50^{\circ}$ C. Mekanisme kerja dari ekstraksi refluks yaitu pelarut yang digunakan akan menguap pada suhu yang digunakan, tetapi akan didinginkan dengan kondensor sehingga pelarut dalam bentuk uap akan mengembun pada kondensor dan turun lagi kedalam wadah reaksi sehingga pelarut akan tetap ada selama reaksi berlangsung (Sulaksono dan Syamsudin, 2012).

Metode ekstraksi maserasi, proses ekstraksi tidak menggunakan pemanasan hanya melibatkan polaritas pelarut untuk menarik senyawa aktif. Mekanisme kerja ekstraksi maserasi yaitu melakukan perendaman pada suhu kamar dan sesekali dikocok untuk menarik senyawa aktif keluar dari dalam sel. Jika dibandingkan dari ke empat metode ekstraksi tersebut maka metode MAE yaitu metode ekstraksi modern menghasilkan kadar flavonoid paling tinggi, sedangkan kadar flavonoid yang paling rendah dihasilkan oleh metode ekstraksi maserasi yaitu metode ekstraksi konvensional. Hasil rendemen ekstrak, metode ekstraksi konvensional menghasilkan rendemen yang paling tinggi dibandingkan dengan rendemen yang dihasilkan oleh metode ekstraksi modern. Rendemen ekstrak tidak berpengaruh terhadap kadar flavonoid, 
rendemen ekstrak yang tinggi belum tentu menghasilkan kadar flavonoid yang tinggi, karena untuk menarik senyawa aktif tergantung dari mekanisme kerja ekstraksi yang digunakan. Penelitian lain menyatakan bahwa tidak semua flavonoid bersifat tahan panas. Sifat ini tergantung pada sejauh mana kandungan flavonoid dalam bahan alam memiliki gugus $\mathrm{OH}$ agar setiap senyawa didalamnya dapat berikatan hidrogen dengan kuat sehingga untuk memutus ikatan ini adanya energi kuat (Sulaksono dan Syamsudin, 2012). Maka dari itu mekanisme kerja metode MAE melibatkan energi paling kuat dibanding metode yang lain. Nilai rendemen yang tinggi, hal ini dimungkinkan ikatan yang terputus terurai menjadi bentuk lain yang tidak bisa menyerap radiasi pada panjang gelombang $433 \mathrm{~nm}$. Hal inilah yang menyebabkan kadar flavonoid dalam daun iler dengan metode MAE lebih tinggi dibanding metode ekstraksi lain.

Berdasarkan analisa statitik dengan uji one way ANOVA pada program SPSS 26, menunjukkan perbedaan yang siginifikan dari masing-masing ekstraksi terhadap kadar dengan nilai siginifikasi kurang dari 0,05. Kemudian dilakukan uji lanjut secara duncan ternyata maserasi berbeda nyata dengan refluks, berbeda nyata dengan MAE, dan berbeda nyata dengan UAE.

\section{KESIMPULAN}

Berdasarkan hasil penelitian dapat diambil kesimpulan sebagai berikut; perbedaan metode ekstraksi memberikan pengaruh yang siginifikan terhadap kadar flavonoid dalam ekstrak etanol daun iler $(\mathrm{P}<0,05)$. Metode ekstraksi yang dengan kadar flavonoid tertinggi pada ekstrak daun iler yaitu metode MAE dengan kadar flavonoid sebesar $0,75 \%$.

\section{SARAN}

Perlu dilakukan penelitian lebih lanjut mengenai penetapan kadar senyawa metabolit menggunakan metode MAE dengan waktu dan suhu yang optimal.

\section{DAFTAR PUSTAKA}

Dalimartha, S. 2000. Tumbuhan Obat (Jilid 2). Trubus Agriwidya. Jakarta.

Departemen Kesehatan RI. 2000. Parameter Standar Umum Ekstrak Tumbuhan Obat. Direktorat Jenderal Pengawasan Obat dan Makanan. Jakarta.

Departemen Kesehatan RI. 2013. Farmakope Hebal. Direktorat Jenderal Pengawasan Obat dan Makanan. Jakarta.

Fairus, S. 2016. Perbandingan metode ekstraksi maserasi dan refluks terhadap kadar fenolik dari ekstrak tongkol jagung (Zea mays L.). Jurnal Konversi, 5(2): 87- 93.

Farida, Y. 2016. Kandungan Flavonoid The Putih (Camelia sinensis L.) Dengan Metode Ekstraksi Ultrasound Assisted Extraction (UAE) Dengan Variasi Suhu Dan Waktu. Skripsi. Universitas Pakuan. Bogor.

Jupersio. 2017. Analisis Kadar Flavonoid Ekstrak Etanol 70\% Kulit Bawang Merah (Allium Cepa L.) Hasil Ekstraksi Metode Maserasi dan MAE (Microwave Assisted Extraction). Skripsi. Universitas Pakuan. Bogor.

Quan, P. T., Hang, T. V., Ha, N. H., De, N. X., \& Tuyen, T. N. 2006. Microwave assisted extraction of polyphenols from fresh tea shoot. Science \& Technology Development, 9 (8): 69-75.

Rahmawati, S. 2018. Formulasi dan Aktivitas Antioksidan Permen Jelly Sari Buah Apel. Skripsi. Universitas 
Pakuan. Bogor.

Riky, A. \& Bambang C. 2014. Efek hidrolisis ekstrak daun iler (Coleus scutellarioides) terhadap aktivitas inhibisi enzim $\alpha$-glukosidase. Jurnal Sains Dan Matematika, 22(1): 1519.

Sulaksono, FB. \& Syamsudin A. 2012. Koreksi kadar flavonoid dan toksisitas dalam ekstrak tempuyung (Sonchus arvensis) dan pegagan (Centella asiatica). Jurnal Konversi, 1(2): 33-42.

Swantara, I. 2010. Isolasi dan identifikasi fraksi toksik ekstrak tumbuhan iler
(Coleus scutellarioides [L.] Benth.). Indonesia Jurnal of Cancer, 4(1): 913.

Yulianti, D., Bambang, S., Rini, Y. 2014. Pengaruh lama ekstraksi dan konsentrasi pelarut etanol terhadap sifat fisika-kimia ekstrak daun stevia (Stevia rebaudiana B. M.) dengan Metode MAE. Jurnal Bioproses Komoditas Tropis, 2(1): 35-41.

Yustina, D. 2015. Aktivitas Antibakteri Ekstrak Etanol Daun Jawer Kotok (Coleus atropurpureus) Terhadap Bakteri Kulit Wajah Berjerawat Skripsi. Universitas Pakuan. Bogor. 